\title{
Adult and pre-breeding survival estimates of the Whiskered Tern Chlidonias hybrida breeding in southern Poland
}

\author{
Mateusz Ledwoń • Grzegorz Neubauer • Jacek Betleja
}

Received: 2 May 2012/Revised: 25 November 2012/Accepted: 19 December 2012/Published online: 13 January 2013

(C) The Author(s) 2013. This article is published with open access at Springerlink.com

\begin{abstract}
We present the first-ever survival estimates of the Whiskered Tern Chlidonias hybrida, based on the analysis of capture-recapture data (403 adults and 1,484 chicks ringed) collected between 1993 and 2011 in an increasing breeding population in southern Poland. Data were modelled using multistate models with an unobservable state, accounting for the period during which young terns remain at their winter quarters. Model-averaged prebreeding and breeding survival were estimated to be 0.54 [standard error (SE) 0.28] and $0.80(\mathrm{SE}=0.05)$, respectively. All models were in agreement that the relative proportion of breeders was nearly zero in the second calendar year, increasing to reach values close to 0.8 in the fifth calendar year, which confirms the observation of a much delayed maturation of the Whiskered Tern. Our data indicate that most Whiskered Tern start to breed about 1 year earlier than members of genera Sterna and Onychoprion. However, the precision of the estimates for the
\end{abstract}

Communicated by P. H. Becker.

Electronic supplementary material The online version of this article (doi:10.1007/s10336-012-0926-z) contains supplementary material, which is available to authorized users.

M. Ledwoń ( $\square)$

Institute of Systematics and Evolution of Animals,

Polish Academy of Sciences, Sławkowska 17,

31-016 Kraków, Poland

e-mail: ledwon@isez.pan.krakow.pl

G. Neubauer

Ornithological Station, Museum and Institute of Zoology,

Polish Academy of Sciences, Nadwiślańska 108,

80-680 Gdańsk, Poland

J. Betleja

Upper Silesian Museum, Department of Natural History,

Plac Jana III Sobieskiego 2, 41-902 Bytom, Poland parameter describing the transition probability from the unobservable pre-breeding to the observable breeding state was extremely poor; therefore, these estimates should be treated as tentative until more data are collected. The three best-supported models indicated significant annual variation in recapture probability. The results also suggested that forced exchange of breeding colonies is frequent in the study area; consequently, a large proportion of birds ringed as chicks are breeding in colonies other than their respective natal colony. This exchange is best explained not by the trapping and ringing activity but by human management of the environment, such as water level changes in dam reservoirs and carp Cyprinus carpio farming at fish ponds, both of which result in breeding habitats becoming unstable and periodically unavailable, possibly forcing birds to change breeding sites.

Keywords Whiskered Tern - Chlidonias hybrida . Capture-mark-recapture modelling - Apparent survival . Age at first breeding · Fidelity - Bird trapping

\section{Zusammenfassung}

Überlebensraten von Weißbartseeschwalben (Chlidonias hybrida) in Süd-Polen vor und nach der ersten Brut

Wir zeigen hier die ersten Überlebensschätzungen von Weißbartseeschwalben (Chlidonias hybrida), basierend auf Fang-Wiederfang Daten (403 adulte und 1484 Küken), die zwischen 1993 und 2011 in einer wachsenden Brutpopulation im südlichen Polen aufgenommen wurden. Wir modellierten die Daten in einem Zustands-Modell (multistate model) mit einem unbeobachteten Zustand zur Modellierung des Zeitraums, in dem die jungen Seeschwalben in ihrem Winterquartier sind. Die über die Modelle gemittelte Überlebensrate bis zur ersten Brut lag bei 
$0,54 \pm 0,28$ (SE), während sie danach $0,80 \pm 0.05$ betrug. Alle Modelle stimmten darin überein, dass der relative Anteil von Brütern im zweiten Kalenderjahr nahezu Null beträgt, danach bis zum 5 . Kalenderjahr auf 0,8 ansteigt. Dies bestätigt die sehr verzögerte Geschlechtsreife bei Weißbartseeschwalben. Unsere Daten deuten weiter darauf hin, dass die meisten Weißbartseeschwalben etwa ein Jahr früher anfangen zu brüten, als Vögel der Gattrungen Sterna und Onychoprion. Die Präzision der Parameter zur Beschreibung der Übergangswahrscheinlichkeit vom unbeobachteten vor-Brut zum beobachteten nach-Brut Zustand war allerdings extrem schlecht, und sie sollten als vorläufig betrachtet werden, bis mehr Daten erhoben wurden. Drei am besten unterstützte Modelle zeigten eine signifikante jährliche Variation in der Wiederfangwahrscheinlichkeit. Die Ergebnisse deuten auch darauf hin, dass regelmäßig ein erzwungener Austausch zwischen den Brutkolonien im Untersuchungsgebiet stattfindet. Daher brütet ein großer Anteil von Vögeln, die als Küken beringt wurden, in anderen als ihren Geburts-Kolonien. Dies erklärt sich nicht durch Fang und Beringung, sondern durch menschliches Umweltmanagement: Wasserstandsänderungen in Stauseen und Karpfen (Cyprinus carpio)-Zuchten in Fischteichen machen Bruthabitate unzuverlässig und zeitweilig unverfügbar, was Vögel dazu gezwungen haben könnte, die Brutorte zu wechseln.

\section{Introduction}

The survival rate in any animal population is a joint product of variations in the rates of birth, death and movements of individuals (Lebreton et al. 1992). Each bird population has a specific pattern of age- and/or sex-related survival that may further depend on multiple factors: year, weather conditions, place of birth, parasite and predatory pressures, food supply, individual condition and individual heterogeneity (Nichols et al. 1990; Spendelow et al. 1995, 2002; Lebreton et al. 2003; Monticelli et al. 2008b; Braasch et al. 2009; Monticelli and Ramos 2012). Demographic data of long-lived birds with delayed maturity show that survival probability differs between age-classes. Pre-breeding survival (defined as the probability of surviving the time before accession to reproduction) is most frequently lower than survival after the individual has reached breeding age (Massey et al. 1992; Spendelow et al. 2002; Lebreton et al. 2003; Collins and Doherty 2006; Szostek and Becker 2012). The lower survival rate of prebreeding birds relative to adult birds is a consequence of the higher mortality of inexperienced young birds (Spendelow 1991; Lebreton et al. 2003). Adult and prebreeding survival are among the key parameters affecting population dynamics (Lebreton et al. 1992). Consequently, estimation of these parameters is of particular importance for assessing population dynamics, understanding life-history parameters and, ultimately, for managing populations (Perrins et al. 1993; Williams et al. 2002).

Terns (subfamily Sterninae) are characterised by high adult survival (annual rates often around 0.90), a long lifespan (usually 10-20 years), low fecundity (usually one brood per year with 1-3 eggs), delayed maturity and faithfulness to their breeding sites (Cramp 1985; Weimerskirch 2002; Braby et al. 2012). Tern species breeding in temperate latitudes migrate long distances to reach winter quarters, where immature birds spend from one to a few years, depending on the species, before their first return to the breeding area (Gochfeld and Burger 1996). They usually do not start breeding upon their first visit to the breeding area. Breeding site fidelity is usually high (around $90 \%$ ), but depends on the site, predation rate, disturbance and distance to other colonies (Spendelow et al. 1995; Lebreton et al. 2003; Devlin et al. 2008, Braby et al. 2012). Cases of distant breeding dispersal $(200-400 \mathrm{~km})$ have also been reported (Spendelow et al. 2010). As in most birds, natal dispersal among terns occurs with a greater probability than breeding dispersal (Greenwood and Harvey 1982; Spendelow 1991; Lebreton et al. 2003).

In terns, survival, lifespan and dispersal rates are known mainly for the well-studied species belonging to genera Sterna, Sternula and Thalasseus, and very little is known about the survival rate in the marsh terns (genus Chlidonias). Marsh and non-marsh terns differ in their preferences for a breeding habitat (Cramp 1985; Gochfeld and Burger 1996). Marsh terns belonging to the genus Chlidonias nest on water plants and inhabit shallow, frequently small reservoirs, such as inland marches, fish ponds and flooded meadows, that commonly dry out during the breeding season; consequently, they may be unpredictable in terms of their suitability as a breeding habitat. Other tern species breed mainly in more predictable (or stable) habitats, such as coasts, islands or artificial nesting platforms. Due to their relative high dependency on the availability of their unstable nesting habitat, marsh terns generally tend to be more nomadic than non-marsh terns. In dry years, species like the White-winged Black Tern Ch. leucopterus may undertake massive movements from areas with an unfavourable breeding habitat to other distant areas-probably even hundreds of kilometres (e.g. Ławicki et al. 2011). For these reasons it is far more difficult to collect the capturerecapture data necessary to estimate survival for marsh terns than for other genera: of the 30 papers addressing tern survival, only two refer to the genus Chlidonias (Shealer 2007; van der Winden and van Horssen 2008, see also Table 4), with survival rate in one study (van der Winden and van Horssen 2008) estimated from a population model, without using capture-recapture data. 
Fig. 1 Water bodies in the Upper Vistula River Valley where the Whiskered Tern were captured during the study period (1993-2011). Fish pond complexes: 1 Spytkowice Kępki, 2 Spytkowice, 3 Przeręb, 4 Bugaj, 5 Rudze, 6 Tomice, 7 Zaborze, 8 Wola. Dam reservoirs: 9 Goczałkowice Reservoir

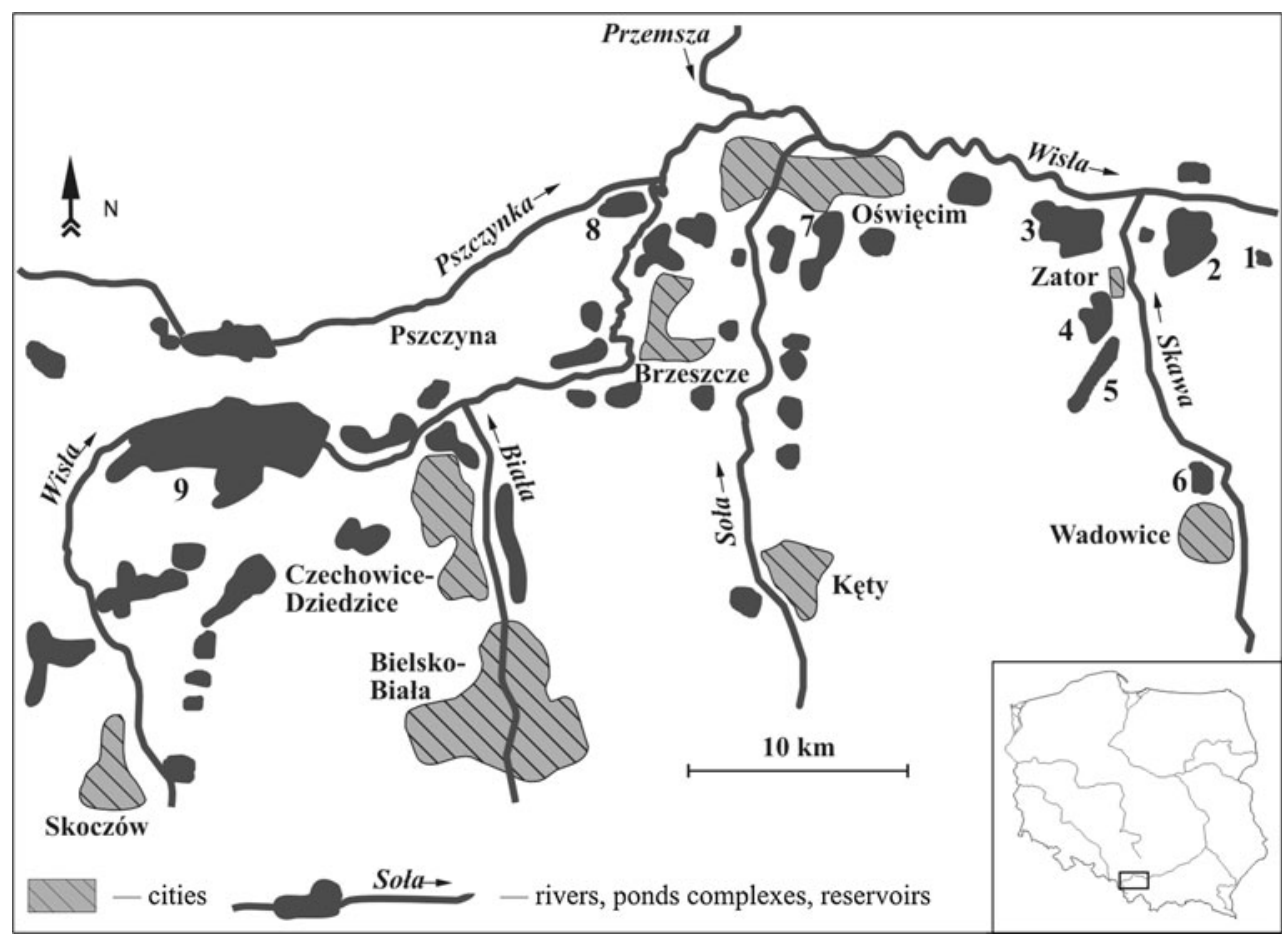

In study reported here we focused on the survival of the Whiskered Tern Ch. hybrida-a marsh tern species whose population has declined in Europe since the 1970s, but which has recovered beginning in 1990, with clear increases in central and eastern parts of the continent (BirdLife International 2004). It has been colonising Polish inland areas for the last three decades: the first breeding was noted in the 1960s (Tomiałojć and Stawarczyk 2003), while in 2007 the population size reached around 1,500 pairs (Komisja Faunistyczna 2008). We have studied the largest and constantly increasing local population in southern Poland for 19 consecutive years to obtain the firstever estimates of apparent survival for this species and have compared these estimates with published data for other tern species. We also addressed another issue that has remained unknown for the Whiskered Tern: the age of first breeding.

\section{Materials and methods}

Study area and field methods

Data were collected in the Upper Vistula River Valley (southern Poland), an area of approximately $1,400 \mathrm{~km}^{2}$ with numerous carp pond complexes and two dam reservoirs [Goczałkowice Reservoir (3,200 ha), Łąka Reservoir (400 ha); Fig. 1]. Carp ponds in the study area are grouped into over 70 complexes (total area approx. 6,000 ha); individual complexes are separated by several kilometres of land, where villages, pastures, arable land and small forests can be found. Each fish complex usually contains from a few to dozens of ponds. The area of each complex varies from 10 to 500 ha (mean $90 \mathrm{ha}$ ).

The presence of Whiskered Tern breeding colonies on a given reservoir depends mainly on the availability of plants on which they build nests. Birds frequently change ponds within and among complexes and dam reservoirs in response to changing conditions, caused mostly by carp farming or a variable water level, respectively. Therefore, for clarity and simplicity, we assumed that all birds nesting at a given fish pond complex and at a respective dam reservoir in any given year formed one 'colony', even if distances between groups of nests were highly variable. Such defined 'colonies' were named after the fish pond complex or dam reservoir. Birds were trapped mainly in two areas-at the Goczałkowice Reservoir $\left(49^{\circ} 55^{\prime} \mathrm{N}\right.$, $\left.18^{\circ} 50^{\prime} \mathrm{E}\right)$ and on the eight carp pond complexes located between the Wola Ponds $\left(49^{\circ} 54^{\prime} \mathrm{N}, 19^{\circ} 29^{\prime} \mathrm{E}\right)$ and Tomice Ponds $\left(49^{\circ} 53^{\prime} \mathrm{N}, 19^{\circ} 28^{\prime} \mathrm{E}\right)$ (Fig. 1).

The number of breeding Whiskered Terns in the Upper Vistula River Valley increased from over 30 pairs in 1993 to about 700 in 2011 (Komisja Faunistyczna 1994; ML, JB, unpublished data). Over this period, birds bred at 32 locations (range 1-15 per year, mean 8 ). On average, about $40 \%$ of the Polish population of the species bred in the Upper Vistula River Valley over the study period. While emigration and immigration between the study population and other populations must play a role, we assume that their impact is currently moderate or low (although the 
rapid increase in the number of breeding pairs in the 1990s in this area must have been largely driven by immigration from Eastern Europe; Betleja 2003) for the following reasons. Firstly, the high availability of suitable habitat (even if not at the same pond complexes or dam reservoir) and plentiful food make the area very attractive to the species, compared to almost waterless surroundings. Secondly, the distance to the closest breeding colonies at the Świerklaniec Reservoir $\left(50^{\circ} 25^{\prime} \mathrm{N}, 18^{\circ} 58^{\prime} \mathrm{E}\right.$; max. 30 breeding pairs; Komisja Faunistyczna 2003) and Turawa Reservoir $\left(50^{\circ} 43^{\prime} \mathrm{N}, 18^{\circ} 07^{\prime} \mathrm{E}\right.$; max. 50 breeding pairs; Komisja Faunistyczna 2002) is about 50 and $100 \mathrm{~km}$, respectively, while the distance between the most distant colonies in the Upper Vistula Valley is approximately $50 \mathrm{~km}$; distances between breeding colonies are usually only a few kilometres (Fig. 1). One Whiskered Tern ringed as a chick at the Turawa Reservoir was trapped while breeding in the Upper Vistula River Valley (ML, unpublished data), but none of the birds ringed in the Upper Vistula River Valley were found breeding elsewhere (though this is likely a result of the scarcity of studies on the species).

The size of each colony ranged from several to more than 150 nests. The Whiskered Tern has a long breeding season, with colonies established from early May to early August. Fieldwork was conducted each year between 1993 and 2011 (19 years) during the entire breeding season. Trapping was not carried out in all of the study years (Electronic Supplementary Material (ESM) Tables 1, 2) nor in all of the colonies; on average, trapping was performed in one-third of occupied sites. In total, 403 adults and 1,484 chicks were ringed in the breeding colonies. Between 1993 and 1997 we only caught birds at the Goczałkowice Reservoir, and between 1998 and 2011 we only caught birds at the fish ponds. This variation in trapping activity was caused by changing numbers of breeding pairs at particular sites. Between 1993 and 1996 the Whiskered Tern was nesting mainly at the Goczałkowice Reservoir; in the period 1998-2002, the whole population bred on fish ponds in the more eastern part of the valley; finally, between 2003 and 2006 from 6 to $65 \%$ of breeding pairs from the Upper Vistula Valley bred at the Goczałkowice Reservoir. The reason for these movements was a change in the habitat at the reservoir coupled with a population increase. Adult birds were caught at the nest with a roof trap or a loop trap (Betleja 2003; Ledwoń 2011). All individuals were ringed, measured, weighed and, in some cases, colour-marked with a dye. Chicks were ringed in the nests or in their vicinity and were 3-21 days old (approximate fledging age is 21 days) when ringed. Adults and chicks were marked with stainless steel rings, although on some occasions birds were also ringed with a combination of colour rings (separate codes for different years) or a numbered colour ring. Due to the lack of data from colour- ringed birds, only captures of steel-ringed breeding birds were included in survival analysis. Nests for trapping were selected at random. No cases of metal ring losses were noted.

During the study period (1993-2011) we estimated the numbers of breeding pairs for all colonies in the Upper Vistula River Valley. We usually counted nests in the breeding colonies, and only on a few occasions did we estimate colony size based on the number of adult birds flying over the colony. All confirmed breeding attempts in the period 1993-2007 were verified by the Rarities Committee.

Trapping and ringing activity: influence on numbers of breeding birds

To test whether trapping and ringing activity in year $t$ affected the probability of decline in the Whiskered Tern's colony in year $t+1$ (i.e., leaving the colony due to disturbance), we applied a generalised linear model (GLM) with logit link function to the activity and numbers data. For each colony and each year, we measured the trappingringing activity in two ways: (1) as the number of days during which ringing visits were made to the colony in year $t$ and (2) as the total number of terns ringed in year $t$ (chicks and adults pooled). We classified changes in the numbers for the year $t+1$ as declines when the numbers were lower than those in year $t$, or as increases (no effect of trapping/ringing activity; this category included no changes in numbers). The trapping-ringing activity variables in a given colony in year $t$ were treated as predictors, likely to affect numbers in year $t+1$; the latter was treated as a binary response variable (declines were coded as ' 1 ' and increases as ' 0 '). This analysis covered a 12 -year period (1999-2010) for which complete data on numbers were available and included 71 colony-year 'datapoints' with breeding terns; the analysis was performed using Statistica ver. 6.0 (StatSoft 2003).

\section{Capture-recapture modelling}

Multistate (multistrata) models with an unobservable state (Pradel and Lebreton 1999; Spendelow et al. 2002; Lebreton et al. 2003; Monticelli et al. 2008b) were used to account for the delayed maturation of young Whiskered Terns. Most young birds stay at their winter quarters during their first summer (2nd calendar year), similar to many other tern species (Cramp 1985; Gochfeld and Burger 1996); observations of 2nd year Whiskered Terns in European breeding colonies are scarce (but see Mees 1977; Cramp 1985; Latraube et al. 2006; see also Results). In multistate models, a young bird enters an unobservable state (hereafter referred to as the pre-breeding state, $\mathrm{P}$ ) after 
being ringed as a chick; it remains unobservable until it returns to breed for the first time, when it becomes observable (hereafter referred to as the breeding state, B) and can possibly be re-encountered as a breeder. Three parameters are estimated under these models: survival probability $S$ (separate estimates for pre-breeders and breeders, $S^{\mathrm{P}}$ and $S^{\mathrm{B}}$ ), recapture probability $p$ (estimated for breeders only, $p^{\mathrm{B}}$, see also below) and transition probability $\psi$ (probability of movement between the states). The last parameter $\left(\psi^{\mathrm{P}-\mathrm{B}}\right)$ refers to the probability of entering the breeding state (i.e., the probability that a bird returned to breeding site to reproduce, conditional on survival). Regardless of the structure of the transition parameter implemented in a given model (i.e. constant vs. age- or time-dependent), cumulative estimates of breeding propensity for subsequent years of life (thus for any age $I$ ) can be computed following Pradel and Lebreton (1999), who describe relationships between three measures of accession to reproduction. In our study, we used the $\gamma$ measure, which reflects the proportion of experienced breeders (i.e. the proportion of birds that have already bred at least once among all breeders of age I; Pradel 1996). An alternative measure, $\beta_{I}$, is easy to interpret and reflects the probability that a breeder of age $I$ is a first-time breeder: $\beta_{I}=1-\gamma_{I}$ (Pradel et al. 1997). Our capture-recapture data refer only to birds trapped at nests and thus individuals for which breeding was confirmed (assessed with $100 \%$ certainty). As a consequence, estimated probabilities of accession to reproduction (Pradel and Lebreton 1999) refer to breeding individuals (i.e. exclude prospective ones).

To account for the unobservable state, recapture probability for Whiskered Terns in a pre-breeding state was fixed at 0 . Only transitions from the unobservable to the observable state are allowed as breeders cannot become non-breeders once they breed and $\psi^{\mathrm{B}-\mathrm{P}}$ equals 0 . These two parameters were fixed in all models fitted to the data and are omitted in notation. For example, the model noted $\operatorname{as}\left\{S_{(.)}^{\mathrm{P}}, S_{(.)}^{\mathrm{B}}, p_{(\mathrm{t})}^{\mathrm{B}}, \psi_{(\mathrm{a}=2)}\right\}$ is the model which accounts for constant survival probabilities for pre-breeders and breeders (but different for each group), time-dependent recapture probability (for breeders) and two 'age'-classes in transition probability $\psi^{\mathrm{P}-\mathrm{B}}$ (as time within cohort equals age). It is important to note here that permanent emigration before reproduction is confounded with death in this model type and that pre-breeding survival may involve some prefledging mortality because the terns were ringed as chicks prior to fledging.

In total, 21 models were fitted to the data (Table 1). To avoid overparameterisation, we omitted the fully parameterised model with time-dependence in two survival parameters and the recapture parameter and three age classes in the transition parameter, due to sparseness of data (this model would have 59 parameters, while there were 56 unique capture histories). Therefore, in our models we allowed for time-dependence in either two survival parameters (then recapture kept constant) or in one survival parameter (the other kept constant) and recapture parameter.

The goodness-of-fit (GOF) test performed in U-CARE ver. 2.3.2 (Choquet et al. 2009) provided no evidence for lack of fit of the general JMV model $\left(\chi^{2}=8.886\right.$, $p=0.883, d f=15)$.

Models were ranked according to AICc (Akaike information criterion corrected for small sample size) values. Because the three best models had relatively high support [ $\triangle \mathrm{AICc}$ (absolute change in AIC units) between the model

Table 1 Models fitted to capture-recapture data of Whiskered Tern Chlidonias hybrida, southern Poland

\begin{tabular}{|c|c|c|c|c|c|}
\hline Model notation & $\mathrm{AICc}$ & $\Delta \mathrm{AICc}$ & $\omega$ & $K$ & Dev \\
\hline$\left\{S_{(.)}^{\mathrm{P}}, S_{(.)}^{\mathrm{B}}, p_{(\mathrm{t})}^{\mathrm{B}}, \psi_{(\mathrm{a}=2)}^{\mathrm{P}-\mathrm{B}}\right\}^{\mathrm{a}}$ & 446.48 & 0.00 & 0.514 & 24 & 86.82 \\
\hline$\left\{S_{(.)}^{\mathrm{P}}, S_{(.)}^{\mathrm{B}}, p_{(\mathrm{t})}^{\mathrm{B}}, \psi_{(.)}^{\mathrm{P}-\mathrm{B}}\right\}$ & 447.74 & 1.26 & 0.274 & 23 & 90.12 \\
\hline$\left\{S_{(.)}^{\mathrm{P}}, S_{(.)}^{\mathrm{B}}, p_{(\mathrm{t})}^{\mathrm{B}}, \psi_{(\mathrm{a}=3)}^{\mathrm{P}-\mathrm{B}}\right\}$ & 448.44 & 1.96 & 0.193 & 25 & 86.73 \\
\hline$\left\{S_{(\mathrm{t})}^{\mathrm{P}}, S_{(.)}^{\mathrm{B}}, p_{(\mathrm{t})}^{\mathrm{B}}, \psi_{(\mathrm{a}=2)}^{\mathrm{P}-\mathrm{B}}\right\}$ & 453.23 & 6.75 & 0.018 & 41 & 70.89 \\
\hline$\left\{S_{(\mathrm{t})}^{\mathrm{P}}, S_{(.)}^{\mathrm{B}}, p_{(\mathrm{t})}^{\mathrm{B}}, \psi_{(\mathrm{a}=3)}^{\mathrm{P}-\mathrm{B}}\right\}$ & 458.80 & 12.32 & 0.001 & 42 & 70.24 \\
\hline$\left\{S_{(.)}^{\mathrm{P}}, S_{(.)}^{\mathrm{B}}, p_{(.)}^{\mathrm{B}}, \psi_{(\mathrm{a}=2)}^{\mathrm{P}-\mathrm{B}}\right\}$ & 462.67 & 16.19 & 0.000 & 7 & 137.52 \\
\hline$\left\{S_{(.)}^{\mathrm{P}}, S_{(.)}^{\mathrm{B}}, p_{(.)}^{\mathrm{B}}, \psi_{(.)}^{\mathrm{P}-\mathrm{B}}\right\}$ & 463.00 & 16.52 & 0.000 & 6 & 139.86 \\
\hline$\left\{S_{(.)}^{\mathrm{P}}, S_{(\mathrm{t})}^{\mathrm{B}}, p_{(\mathrm{t})}^{\mathrm{B}}, \psi_{(\mathrm{a}=2)}^{\mathrm{P}-\mathrm{B}}\right\}$ & 464.40 & 17.92 & 0.000 & 41 & 758.41 \\
\hline$\left\{S_{(.)}^{\mathrm{P}}, S_{(.)}^{\mathrm{B}}, p_{(.)}^{\mathrm{B}}, \psi_{(\mathrm{a}=3)}^{\mathrm{P}-\mathrm{B}}\right\}$ & 464.49 & 18.01 & 0.000 & 8 & 137.32 \\
\hline$\left\{S_{(\mathrm{t})}^{\mathrm{P}}, S_{(.)}^{\mathrm{B}}, p_{(\mathrm{t})}^{\mathrm{B}}, \psi_{(.)}^{\mathrm{P}-\mathrm{B}}\right\}$ & 464.95 & 18.47 & 0.000 & 40 & 763.89 \\
\hline$\left\{S_{(.)}^{\mathrm{P}}, S_{(\mathrm{t})}^{\mathrm{B}}, p_{(\mathrm{t})}^{\mathrm{B}}, \psi_{(\mathrm{a}=3)}^{\mathrm{P}-\mathrm{B}}\right\}$ & 466.27 & 19.79 & 0.000 & 42 & 756.31 \\
\hline$\left\{S_{(\mathrm{t})}^{\mathrm{P}}, S_{(.)}^{\mathrm{B}}, p_{(.)}^{\mathrm{B}}, \psi_{(\mathrm{a}=2)}^{\mathrm{P}-\mathrm{B}}\right\}$ & 467.51 & 21.02 & 0.000 & 24 & 116.02 \\
\hline$\left\{S_{(.)}^{\mathrm{P}}, S_{(\mathrm{t})}^{\mathrm{B}}, p_{(\mathrm{t})}^{\mathrm{B}}, \psi_{(.)}^{\mathrm{P}-\mathrm{B}}\right\}$ & 468.42 & 21.94 & 0.000 & 40 & 798.61 \\
\hline$\left\{S_{(\mathrm{t})}^{\mathrm{P}}, S_{(.)}^{\mathrm{B}}, p_{(.)}^{\mathrm{B}}, \psi_{(\mathrm{a}=3)}^{\mathrm{P}-\mathrm{B}}\right\}$ & 469.72 & 23.24 & 0.000 & 25 & 114.15 \\
\hline$\left\{S_{(\mathrm{t})}^{\mathrm{P}}, S_{(.)}^{\mathrm{B}}, p_{(.)}^{\mathrm{B}}, \psi_{(.)}^{\mathrm{P}-\mathrm{B}}\right\}$ & 473.59 & 27.11 & 0.000 & 23 & 120.07 \\
\hline$\left\{S_{(.)}^{\mathrm{P}}, S_{(\mathrm{t})}^{\mathrm{B}}, p_{(.)}^{\mathrm{B}}, \psi_{(.)}^{\mathrm{P}-\mathrm{B}}\right\}$ & 487.57 & 41.09 & 0.000 & 23 & 129.95 \\
\hline$\left\{S_{(.)}^{\mathrm{P}}, S_{(\mathrm{t})}^{\mathrm{B}}, p_{(.)}^{\mathrm{B}}, \psi_{(\mathrm{a}=2)}^{\mathrm{P}-\mathrm{B}}\right\}$ & 488.11 & 41.63 & 0.000 & 24 & 132.54 \\
\hline$\left\{S_{(.)}^{\mathrm{P}}, S_{(\mathrm{t})}^{\mathrm{B}}, p_{(.)}^{\mathrm{B}}, \psi_{(\mathrm{a}=3)}^{\mathrm{P}-\mathrm{B}}\right\}$ & 490.15 & 43.67 & 0.000 & 25 & 132.54 \\
\hline$\left\{S_{(\mathrm{t})}^{\mathrm{P}}, S_{(\mathrm{t})}^{\mathrm{B}}, p_{(\cdot)}^{\mathrm{B}}, \psi_{(\mathrm{a}=2)}^{\mathrm{P}-\mathrm{B}}\right\}$ & 492.02 & 45.54 & 0.000 & 41 & 107.61 \\
\hline$\left\{S_{(\mathrm{t})}^{\mathrm{P}}, S_{(\mathrm{t})}^{\mathrm{B}}, p_{(.)}^{\mathrm{B}}, \psi_{(\mathrm{a}=3)}^{\mathrm{P}-\mathrm{B}}\right\}$ & 494.27 & 47.79 & 0.000 & 42 & 105.71 \\
\hline$\left\{S_{(\mathrm{t})}^{\mathrm{P}}, S_{(\mathrm{t})}^{\mathrm{B}}, p_{(.)}^{\mathrm{B}}, \psi_{(.)}^{\mathrm{P}-\mathrm{B}}\right\}$ & 500.21 & 53.73 & 0.000 & 40 & 113.73 \\
\hline
\end{tabular}

AICc, Akaike information criterion corrected for small sample size; $\triangle \mathrm{AICc}$, absolute difference in AIC units between a given model and the best-supported model; $\omega$, AICc weight; $K$, number of parameters; Dev, deviance

Note that two parameters fixed at $0\left(p^{\mathrm{P}}\right.$ and $\left.\psi^{\mathrm{B}-\mathrm{P}}\right)$ are omitted in notation of models to keep it simple

a The best-supported model 
with the highest rank, the second- best model and the thirdbest model was $\leq 2$ ], we calculated model-averaged parameter esimates (Burnham and Anderson 2002). In this procedure, estimates are calculated from all models in the set using model-specific weights reflecting the degree of support for the given model (i.e. the more equal the weights, the less certainty which model is the best). Model construction and fitting were performed using MARK ver. 5.1 (White and Burnham 1999).

\section{Results}

\section{Survival estimates}

Of the 21 models that were fitted to the data, three were equally good $(\Delta \mathrm{AICc}<2)$ and had effectively all support (cumulative Akaike weight $\omega>0.98$; Table 1). These three models had constant survival for both pre-breeders and breeders and time-dependent recapture. The model with the highest support $(\omega=0.514)$ was the one that assumed a constant survival of both pre-breeders and adults over time but which was different for each group, with a time-dependent recapture probability and transition probability with two age-classes. Under this model, pre-breeding survival was estimated to be 0.51 [standard error $(\mathrm{SE})=0.21$; confidence interval (CI) 0.17-0.84] while breeding (adult) apparent survival was much higher and estimated at 0.79 ( $\mathrm{SE}=0.06$, CI 0.67-0.88). The secondbest model, with comparable support $(\omega=0.273)$ had a higher pre-breeding survival estimate $\left(S^{\mathrm{P}}=0.63\right.$, $\mathrm{SE}=0.15)$ and nearly the same breeding survival estimate $\left(S^{\mathrm{B}}=0.81, \mathrm{SE}=0.06\right)$ Model-averaged estimates of survival were very similar to the ones from the best-supported model $\left(S^{\mathrm{P}}=0.54 \pm 0.28 \mathrm{SE}, S^{\mathrm{B}}=0.80 \pm 0.05 \mathrm{SE}\right)$. All three models with meaningful support had time-dependent structure of the recapture parameter, suggesting significant annual variation in the recapture probability of breeders. The probability of recapture was very low and varied between 0 and 0.09 , depending on year.

\section{Age at first breeding}

During the study one bird ringed as a chick was trapped when breeding in the third calendar year, another one in the fourth calendar year and two birds were trapped at nests when they were 5 years old; all remaining birds ringed as chicks were retrapped when they were older (ESM Table 2). No birds were trapped at nests in the second calendar year. Two individuals of this age were observed in a breeding colony (they were recognised by unnumbered colour rings); however they were prospectors rather than breeders.
The results from modelling supported the fact that only few Whiskered Terns start breeding before their third calendar year. Model-averaged $\psi^{\mathrm{P}-\mathrm{B}}$ values were $0.02,0.25$ and 0.30 in their second, third and fourth calendar years of life. Cumulative model-averaged probabilities of being an experienced breeder $(\gamma)$ were 0.03 in the second calendar year, 0.37 in the third year, 0.62 in the fourth year, 0.77 in the fifth year, and around 0.9 in subsequent years. The associated values of $\beta_{i}$ (the probability that a bird is a firsttime breeder) declined with age due to an increasing proportion of birds having bred prior to a given year and were 0.97 (2nd year), 0.63 (third year), 0.37 (fourth year), 0.23 (fifth year) and around 0.10 later on. The precision of the $\psi^{\mathrm{P}-\mathrm{B}}$ estimates was, however, extremely poor (CIs frequently ranged from 0 to 1 ), and the estimates are best treated as tentative until more data are collected.

Site fidelity and natal site recruitment

Twenty-five Whiskered Tern individuals were recaptured at least once after ringing as adults. Among these, equal proportions were recaptured in the same and different colonies (Table 2), indicating high turnover between colonies in adult birds (and, at the same time, low site fidelity). Among 13 birds ringed as chicks, eight (62\%) were recaptured in colonies other than the respective natal colony.

Trapping and ringing activity: influence on numbers of breeding birds

Among 71 colony-years with breeding Whiskered Terns (the data included in the GLM) there were 39 declines and 32 increases in following years, but neither trapping nor ringing activity significantly affected the probability of the decline (Table 3 ). On average, trapping and ringing activity (i.e. numbers of visits and numbers of ringed birds) were similar in colonies where there was a decline in the

Table 2 Breeding-site fidelity of adult Whiskered Terns in the Upper Vistula River Valley, southern Poland, 1993-2011

\begin{tabular}{lllll}
\hline $\begin{array}{l}\text { Colony site } \\
\text { ringed }\end{array}$ & $\begin{array}{l}\text { Number of ringed } \\
\text { birds }\end{array}$ & $\begin{array}{l}\text { Colony site } \\
\text { recaptured }\end{array}$ & \multirow{2}{l}{$\begin{array}{l}\text { Site fidelity } \\
(\%)\end{array}$} \\
\cline { 3 - 4 } & & Same & Different & \\
\hline Spytkowice & 100 & 4 & 2 & 67 \\
Bugaj & 123 & 7 & 9 & 44 \\
Przeręb & 44 & 2 & 1 & 67 \\
Wola & 12 & 0 & 1 & 0 \\
Total & 279 & 13 & 13 & 50 \\
\hline
\end{tabular}

Only data for colonies where adults were recaptured are shown (Fig. 1) 
Table 3 Factors affecting the probability of decline in Whiskered Tern colonies-results of the generalised linear model

\begin{tabular}{|c|c|c|c|c|}
\hline \multirow[t]{2}{*}{ Effect } & \multicolumn{2}{|l|}{ Colonies } & \multirow[t]{2}{*}{ Wald $\chi^{2}$} & \multirow[t]{2}{*}{$p$} \\
\hline & $\begin{array}{l}\text { With declines } \\
(n=39)\end{array}$ & $\begin{array}{l}\text { Without declines } \\
(n=32)\end{array}$ & & \\
\hline $\begin{array}{l}\text { Number of } \\
\text { visits }\end{array}$ & $2.7 \pm 0.7$ & $2.3 \pm 0.7$ & 0.277 & 0.599 \\
\hline $\begin{array}{l}\text { Number of } \\
\text { ringed terns }\end{array}$ & $16.4 \pm 5.2$ & $15.4 \pm 4.2$ & 0.055 & 0.815 \\
\hline
\end{tabular}

Values are given as the mean \pm standard error (SE)

year following the trapping year and where numbers were stable or increasing.

\section{Discussion}

\section{Adult survival}

In the Whiskered Tern, as in many other terns and gulls, adult survival among our study population was higher than pre-breeding survival (e.g. Spendelow et al. 2002; Lebreton et al. 2003, Monticelli et al. 2008b, Braby et al. 2011; Feare and Doherty 2011; Braby et al. 2012). The data presented here are the first estimates of survival for this species. Based on our data, the survival rate of adult Whiskered Terns $(0.80)$ is similar to that of other tern species (Table 4). To date, only two estimates have been published for the genus Chlidonias, both for the Black Tern $C h$. niger. Van der Winden and van Horssen (2008) used a population model and estimated the annual survival rate in the Dutch Black Tern population to be 0.85 . The annual survival rate in the (declining) Wisconsin population estimated by Shealer (2007), which is based on the capturerecapture approach and thus directly comparable with our estimate for the Whiskered Tern, is surprisingly low at 0.62. The estimate by van der Winden and van Horssen (2008) was obtained using a different method with numerous assumptions (i.e. closeness of the studied population) - thus its comparability to our estimate may be limited.

The breeding of Whiskered Tern on particular fish pond complexes and reservoirs in the Upper Vistula River Valley depends largely on the availability of water plantsmainly Fringed Water-lily Nymphoides peltata and Knotweed Polygonum sp.- on which these birds build their nests. Because the availability of appropriate breeding habitats varies in space and time due to carp farming and a changing water level in the dam reservoirs, the numbers of breeding Whiskered Terns vary accordingly. Our results suggest high breeding dispersal rates (on a small-scale, that is, within the Upper Vistula River Valley) may result in a low recapture probability. Frequent habitat manipulations lead to unpredictable (in the biological sense) spatiotemporal disappearances and occurrences of the breeding habitat, forcing birds to move to other ponds or allowing them to settle in a location that was previously unsuitable. Alternatively, the fieldwork 'design' may also have negatively biased the recapture data: the trapping of breeders was not performed in all colonies nor on an annual basis (ESM Table 1). Determining the rates of emigration and immigration requires the use of a multistate model applied to multisite data (Nichols and Kendall 1995; Spendelow et al. 1995; Lebreton et al. 2003), but due to limitations in the dataset we were unable to apply this model version.

In summary, it would appear that marsh terns (genus Chlidonias) exhibit a similar adult annual survival rate to that of other tern species (Table 4). However, as marsh terns depend on unpredictable breeding habitats (inland marches, fish ponds, flooded meadows), they should exhibit a higher degree of nomadism/emigration than 'non-marsh terns' and, consequently, a lower survival rate (Robinson and Oring 1997; Braby et al. 2012). Our data show-as do data of other studies - that an unpredictable breeding habitat yields low breeding site fidelity (Robinson and Oring 1997; Southern and Southern 1982). This 'unpredictability' in our case can be attributed mainly to human activity.

\section{Pre-breeding survival}

The pre-breeding survival estimates presented here for the Whiskered Tern fall in the middle of the range of estimates known for other tern species (Table 4). However, again, comparability between studies might be limited because published estimates have been obtained using different approaches. Also, variation in estimated pre-breeding survival is partly introduced by the age at which chicks are ringed, which also varies in the different published studies. Chicks ringed closer to fledging provide a higher estimate of survival to recruitment than chicks ringed soon after hatching, indicating that substantial mortality occurs between hatching and fledging (Robinson 2010; Braby et al. 2011). Our pre-breeding survival estimate (0.54) is much higher than the only other estimate obtained for a tern of the same genus-the Black Tern in Wisconsin, USA $(<0.02 \%$; Shealer 2007). In both our study and that of Shealer (2007), the pre-breeding survival estimate includes some pre-fledging mortality. In the Wisconsin study, Black Terns suffered a high degree of nest failure due to strong predation and a relatively low mean number of fledglings per pair (0.5-0.8; Shealer 2007). In the Upper Vistula Valley predatory pressure is low, allowing for high productivity-1.9 fledglings per breeding pair on average (Betleja 2003). 
Table 4 Estimates of survival rates of terns

\begin{tabular}{|c|c|c|c|c|}
\hline Species & Annual adult survival rate & Pre-breeding survival rate & Method $^{\mathrm{a}}$ & References \\
\hline Antarctic Tern Sterna vittata & $0.91(\mathrm{SE}=0.02)$ & & CMR & Sagar et al. (2007) \\
\hline Arctic Tern Sterna paradisaea & $\begin{array}{l}0.798-0.939 \text { (range) }(\mathrm{SE}=0.078 \text {, } \\
0.013)\end{array}$ & & CMR & Devlin et al. (2008) \\
\hline Black Noddy Anous minutus & 0.750 & & $\mathrm{RR}$ & Tarburton (1987) \\
\hline $\begin{array}{l}\text { Whiskered Tern Chlidonias } \\
\text { hybrida }\end{array}$ & $0.80(\mathrm{SE}=0.05)$ & $0.54(\mathrm{SE}=0.28)$ & CMR & This study \\
\hline \multirow[t]{2}{*}{ Black Tern Chlidonias niger } & 0.849 & 0.595 & LSM & $\begin{array}{l}\text { van der Winden and } \\
\text { van Horssen (2008) }\end{array}$ \\
\hline & 0.620 & $<0.02$ & CMR & Shealer (2007) \\
\hline \multirow[t]{3}{*}{ Caspian Tern Hydroprogne caspia } & $0.91(0.84-0.95)$ & $0.86(0.75-0.93)^{\mathrm{b}}$ & CMR & Suryan et al. (2004) \\
\hline & $0.84(0.81-0.86)$ & $0.76(0.71-0.81)^{\mathrm{b}}$ & & \\
\hline & $0.82(\mathrm{SE}=0.03)$ & & CMR & Collins et al. (2010) \\
\hline \multirow[t]{4}{*}{ Common Tern Sterna hirundo } & $0.88-0.92$ (range) & & CMR & Nisbet and Cam (2002) \\
\hline & $0.91(0.870-0.970)$ & $0.35(0.220-0.480)$ & $\mathrm{RR}$ & Becker et al. (2001) \\
\hline & $0.90(\mathrm{SE}=0.06)$ & $0.28-0.36$ (range) $(\mathrm{SE}=0.09)$ & CMR & $\begin{array}{l}\text { Szostek and Becker } \\
\text { (2012) }\end{array}$ \\
\hline & 0.924 (female), 0.835 (male) & & CMR & Ezard et al. (2006) \\
\hline \multirow{2}{*}{$\begin{array}{l}\text { Damara Tern Sternula } \\
\text { balaenarum }\end{array}$} & $0.88(0.72-0.96)$ & & CMR & Braby et al. (2012) \\
\hline & & $0.59(0.48-0.69)^{\mathrm{b}}$ & CMR & Braby et al. (2011) \\
\hline \multirow[t]{2}{*}{ Least Tern Sternula antillarum } & $0.850(0.73-0.95)$ & & CMR & $\begin{array}{l}\text { Renken and Smith } \\
\text { (1995) }\end{array}$ \\
\hline & $\begin{array}{l}0.79-0.92 \text { (range) }(0.88-0.95 \\
0.68-0.89)\end{array}$ & $\begin{array}{l}0.03-0.16 \text { (range) }(0.01-0.05 \\
0.13-0.18)\end{array}$ & CMR & Massey et al. (1992) \\
\hline Little Tern Sternula albifrons & $0.948(0.874-0.948)$ & & & Tavecchia et al. (2005) \\
\hline \multirow[t]{10}{*}{ RoseateTern Sterna dougalli } & $0.901(\mathrm{SE}=0.082)^{\mathrm{c}}$ & & CMR & O’Neill et al. (2008) \\
\hline & $0.819(\mathrm{SE}=0.130)$ & & & \\
\hline & $0.85(0.64-0.98$ range $)$ & 0.38 (range $0.06-0.59$ ) & CMR & Lebreton et al. (2003) \\
\hline & $0.807(\mathrm{SE}=0.033)$ & & CMR & Monticelli et al. (2008a) \\
\hline & $0.835(\mathrm{SE}=0.006)$ & & CMR & Spendelow et al. (2008) \\
\hline & $0.74-0.94$ (range) & & CMR & Spendelow et al. (1995) \\
\hline & $0.73-0.86$ (range) & 0.52 & CMR & Monticelli et al. (2008b) \\
\hline & $0.71-0.90$ (range) & $0.315-0.48$ (range) & CMR & $\begin{array}{l}\text { Nisbet and Ratcliffe } \\
\text { (2008) }\end{array}$ \\
\hline & $0.71-0.80$ (range) & 0.31 & CMR & Shealer et al. (2005) \\
\hline & $0.59-0.92$ (range) & $(0.33-0.68)$ (range) & CMR & Spendelow et al. (2002) \\
\hline $\begin{array}{l}\text { Black-fronted Tern Sterna } \\
\text { albostriata }\end{array}$ & $0.88-0.92$ (range) & & CMR & Kedwell (2005) \\
\hline Royal Tern Thalasseus maximus & $0.95(0.88-0.98)$ & & CMR & $\begin{array}{l}\text { Collins and Doherty } \\
\text { (2006) }\end{array}$ \\
\hline \multirow{2}{*}{$\begin{array}{l}\text { Sandwich Tern Sterna } \\
\text { sandvicensis }\end{array}$} & $0.87(\mathrm{SE}=0.03)$ & $0.32(\mathrm{SE}=0.14)^{\mathrm{a}}$ & CMR & Robinson (2010) \\
\hline & $0.94(\mathrm{SE}=0.13)$ & $0.25(\mathrm{SE}=0.13)^{\mathrm{a}}$ & & \\
\hline \multirow[t]{2}{*}{ Sooty Tern Onychoprion fuscatus } & $0.910(0.89-0.93)$ & & CMR & $\begin{array}{l}\text { Feare and Doherty } \\
\text { (2004) }\end{array}$ \\
\hline & & $0.767(\mathrm{SE}=0.208)$ & CMR & $\begin{array}{l}\text { Feare and Doherty } \\
\text { (2011) }\end{array}$ \\
\hline
\end{tabular}

Data are presented as the estimated survival rate, with either the $95 \%$ confidence interval (CI) or SE given in parentheses

CMR, Capture-mark-recapture refers to a family of models (e.g. Cormack-Jolly-Seber); RR, return rate; LSM, least square model

${ }^{a}$ Annual juvenile survival

b Annual pre-breeding survival rate

${ }^{c}$ Wintering (not breeding) 
During the non-breeding season, Whiskered Terns from Poland probably migrate to and winter on lakes in northern Egypt (Cramp 1985). It remains largely unknown which mortality factors affect young and adult Whiskered Terns in that region, but incidental hunting and pesticides may pose threats to the survival of the birds in their wintering grounds.

\section{Breeding lifespan}

The Whiskered Tern can be long lived; in our study the oldest individuals were ringed as chicks in 2000 and captured as breeding adults in 2010 (ESM Table 1). The oldest known Whiskered Tern on which data are available was 13 years old, and two other birds were at least 10 years old (Latraube et al. 2006). The expected breeding (adult) lifespan calculated from the survival estimates in our study was about 5 years (calculated following Seber 1982), which seems to be slightly lower than that for other tern species; however, given the unknown size of emigration we believe this may be an underestimation (see references in Table 4).

\section{First time breeding}

Little is known about the age of the Whiskered Tern at first time breeding (Mees 1977; Cramp 1985; Latraube et al. 2006). The data presented here are the first-tentativeestimates of the transition to reproduction for the species. During our study, one bird in the third calendar year was trapped at a nest with eggs, while the remaining trapped breeding birds ringed as chicks were at least in their fourth calendar year. We are unable, however, to prove that these individuals did not breed prior to their fourth calendar year. Two birds, identified from unique combinations of colour rings, were found in a breeding area in their second calendar year, but no breeding attempts were confirmed. Whiskered Terns in their second calendar year were found on breeding grounds in France, and it has been suggested that some birds at this age could start to breed (Latraube et al. 2006). We are unable to evaluate exactly which fraction of Whiskered Terns in their second calendar year could visit their breeding area as prospective breeders because our field work focused mainly on trapping adult birds in nests-and not on searching for birds with coloured rings. However, our results are consistent with data reported on the Black Tern: in this species most birds in their second calendar year stay at their wintering grounds, and only a minority visit breeding areas; in their third calendar year, birds may attempt breeding, but are rarely successful (Cramp 1985; van der Winden and van Horssen 2008). The poor precision of the $\psi^{\mathrm{P}-\mathrm{B}}$ estimates prevents us from drawing any conclusions, but all models are in agreement in terms of the fact that the relative proportion of breeders in their second calendar year is very low and increases with age to reach values close to 1 (all birds are breeders) from around the fifth calendar year onwards. These results support the concept of a delayed maturation of the Whiskered Tern. In general, our data indicate that most individuals start breeding around their third and fourth calendar year, with the proportion of experienced breeders being $37 \%$ in the third year, $62 \%$ in the fourth calendar year and $77 \%$ in the fifth calendar year. Agespecific breeding probabilities have also been estimated in other tern species, indicating that most Whiskered Terns would appear to start breeding about 1 year earlier than members of the genera Sterna and Onychoprion (Ludwigs and Becker 2002; Spendelow et al. 2002; Lebreton et al. 2003; Braby et al. 2011; Feare and Doherty 2011).

Trapping and ringing activity: influence on numbers of breeding birds

Intensive trapping of birds generally might contribute to the high emigration rate of birds. Terns disturbed by research activity may exhibit a higher-than-natural level of nest desertion and/emigration, or they may learn to avoid traps and become almost non-catchable (e.g. Nisbet 1978; Kania 1992). Our results suggest that trapping and ringing activity did not have a significant effect on the probability of decline (in other words, the probability of decline was similar in colonies where trapping was performed and where it was not). Colonies of Whiskered Terns showed wide fluctuations in numbers from year to year and frequently disappeared in the years following seasons when no trapping and ringing were performed. Therefore, changes in numbers would appear to depend on human fishing management rather than on our ringing activity. The results of the GLM confirm this: the trapping and ringing activity did not influence the numbers of breeding birds.

Acknowledgments We are grateful for the collaboration of local fish farmers. We also thank the many volunteers who assisted in the fieldwork. Two anonymous referees greatly improved the final version of the paper. The study was partially financially supported by grants from the Ministry of Science and Higher Education (30402731/ 0904).

Open Access This article is distributed under the terms of the Creative Commons Attribution License which permits any use, distribution, and reproduction in any medium, provided the original author(s) and the source are credited.

\section{References}

Becker PH, Wendeln H, González-Solis J (2001) Population dynamics, recruitment, individual quality and reproductive strategies in Common Terns Sterna hirundo marked with transponders. Ardea 89:241-252 
Betleja J (2003) Ecological conditions of the expansion of Whiskered Tern (in Polish). PhD dissertation. University of Wrocław, Wrocław

BirdLife International (2004) Birds in Europe: population estimates, trends and conservation status. BirdLife Conservation Series No. 12. BirdLife International, Cambridge

Braasch A, Schauroth C (2009) Becker PH (2009) Post-fledging body mass as a determinant of subadult survival in Common Terns Sterna hirundo. J Ornithol 150:401-407

Braby J, Braby SJ, Braby RJ, Altwegg R (2011) Immature survival and age at first breeding of Damara Terns: conservation from a non-breeding perspective. Ardea 99:185-190

Braby J, Braby SJ, Braby RJ, Altwegg R (2012) Annual survival and breeding dispersal of a seabird adapted to a stable environment: implications for conservation. J Ornithol. doi:10.1007/s10336011-0798-7

Burnham KP, Anderson DR (2002) Model selection and multimodel inference: a practical information-theoretic approach, 2nd edn. Springer, New York

Choquet R, Lebreton J-D, Gimenez O, Reboulet A-M, Pradel R (2009) U-CARE: utilities for performing goodness-of-fit test and manipulating capture-recapture data. Ecography 32:1071-1074

Collins ChT, Doherty PF Jr (2006) Survival estimates for Royal Terns in southern California. J Field Ornithol 77:310-314

Collins CT, Doherty PF Jr, Knapp PL (2010) Intercolony movement and survival of Caspian Terns in Southern California. North Am Bird Bander 35:175-178

Cramp S (ed) (1985) The birds of the Western Palearctic, vol 4. Oxford University Press, Oxford

Devlin CM, Diamond AW, Kress SW, Hall CS, Welch L (2008) Breeding dispersal and survival of Arctic Terns (Sterna paradisaea) nesting in the Gulf of Maine. Auk 125:850-858

Ezard THG, Becker PH, Coulson T (2006) The contributions of age and sex to variation in Common Tern population growth rate. J Anim Ecol 75:1379-1386

Feare ChJ, Doherty PF Jr (2004) Survival estimates of adult Sooty Terns Sterna fuscata from Bird Island, Seychelles. Ibis 146:475-480

Feare ChJ, Doherty PF Jr (2011) Age at first breeding and prebreeding survival in Seychelles Sooty Terns Onychoprion fuscatus. Mar Ornithol 39:221-226

Gochfeld M, Burger J (1996) Family Sternidae (Terns). In: Del Hoyo J, Elliott A, Sargatal J (eds) Handbook of the birds of the world, vol 3. Hoatzin to Auks. Lynx Editions, Barcelona, pp 624-668

Greenwood PJ, Harvey PH (1982) The natal and breeding dispersal of birds. Annu Rev Ecol Syst 13:1-21

Kania W (1992) Safety of catching adult European birds at the nest. Ring 14:5-50

Kedwell RJ (2005) Breeding biology of Black-fronted Terns (Sterna albostriata) and the effects of predation. Emu 105:39-47

Komisja Faunistyczna SO PTZool (Polish Rarities Committee) (1994) Rare birds recorded in Poland in 1993 (in Polish). Not Orn 35: 331-346

Komisja Faunistyczna SO PTZool (Polish Rarities Committee) (2002) Rare birds recorded in Poland in 2001 (in Polish). Not Orn 43: 177-195

Komisja Faunistyczna SO PTZool (Polish Rarities Committee) (2003) Rare birds recorded in Poland in 2003 (in Polish). Not Orn 44: 195-219

Komisja Faunistyczna SO PTZool (Polish Rarities Committee) (2008) Rare birds recorded in Poland in 2007 (in Polish). Not Orn 49: $81-11$

Latraube F, Mortreux S, Bretagnolle V (2006) Early results from ringing Whiskered Tern Chlidonias hybridus chicks in the Brenne (in French). Alauda 74:271-274
Ławicki Ł, Niedźwiecki S, Sawicki W, Świętochowski P, Goławski A, Kasprzykowski Z, Urban M, Wylegała P, Czechowski P, Prange M, Janiszewski T, Menderski S, Lenkiewicz W, Jantarski M (2011) Numerous nesting of the White-winged Tern Chlidonias leucopterus in Poland in 2010 (in Polish). Ornis Polonica 52:85-96

Lebreton JD, Burnham KP, Clobert J, Anderson DR (1992) Modeling survival and testing biological hypotheses using marked animals: a unified approach with case studies. Ecol Monogr 62:67-118

Lebreton JD, Hines JE, Pradel R, Nichols JD, Spendelow JA (2003) Estimation by capture-recapture of recruitment and dispersal over several sites. Oikos 101:253-264

Ledwoń M (2011) Sexual size dimorphism, assortative mating and sex identification in the Whiskered Tern Chlidonias hybrida. Ardea 99:191-198

Ludwigs JD, Becker PH (2002) The hurdle of recruitment: influences of arrival date, colony experience and sex in the common tern Sterna hirundo. Ardea 90:389-399

Massey BW, Bradley DW, Atwood JL (1992) Demography of a California Least Tern colony including effects of the 1982-83 El Niño. Condor 94:976-983

Mees GF (1977) The subspecies of Chlidonias hybridus (Pallas), their breeding distribution and migrations (Aves, Laridae, Sternidae). Zool Verhandelingen 157:3-64

Monticelli D, Ramos JA (2012) Laying date, body mass and tick infestation of nestling tropical Roseate Terns Sterna dougallii predict fledging success, first-year survival and age at first return to the natal colony. Ibis $154: 825-837$

Monticelli D, Ramos JA, Guerrero-Milheiras SA, Doucet JL (2008a) Adult survival of tropical Roseate Terns breeding on Aride Island, Seychelles, Western Indian Ocean. Waterbirds 31:330-337

Monticelli D, Ramos JA, Hines JE, Nichols JD, Spendelow JA (2008b) Juvenile survival in a tropical population of Roseate Terns: interannual variation and effect of tick parasitism. Mar Ecol Prog Ser 365:277-287

Nichols JD, Kendall WL (1995) The use of multi-state capturerecapture models to address questions in evolutionary ecology. J Appl Stat 22:835-846

Nichols JD, Spendelow JA, Hines JE (1990) Capture-recapture estimation of prebreeding survival rate for birds exhibiting delayed maturation. J Field Ornithol 61:347-354

Nisbet ICT (1978) Population models for Common Terns in Massachusetts. Bird-Banding 49:50-58

Nisbet ICT, Cam E (2002) Test for age-specificity in survival of the Common Tern. J Appl Statistics 29:65-83

Nisbet ICT, Ratcliffe N (2008) Comparative demographics of tropical and temperate Roseate Terns. Waterbirds 31:346-356

O'Neill P, Minton CDT, Nisbet ICT, Hines JE (2008) Annual recapture and survival rates of two nonbreeding adult populations of Roseate Terns Sterna dougallii captured on the Great Barrier Reef, Australia, and estimates of their population sizes. Waterbirds 31:338-345

Perrins CM, Lebreton JD, Hirons GJM (1993) Bird population studies: relevance to conservation and management. Oxford University Press, Oxford, UK

Pradel R (1996) Utilization of capture-mark-recapture for the study of recruitment and population growth rate. Biometrics 52:703-709

Pradel R, Lebreton JD (1999) Comparison of different approaches to study the local recruitment of breeders. Bird Study 46:74-81

Pradel R, Johnson AR, Viallefont A, Nager RG, Cézilly F (1997) Local recruitment in the Greater Flamingo: a new approach using capture-mark-recapture data. Ecology 78:1431-1445

Renken RB, Smith JW (1995) Annual adult survival of interior Least Terns. J Field Ornithol 66:112-116

Robinson RA (2010) Estimating age-specific survival rates from historical ringing data. Ibis 152:651-653 
Robinson JA, Oring LW (1997) Natal and breeding dispersal of American Avocets. Auk 114:416-430

Sagar PM, Miskelly CM, Scofield RP, Sagar RP (2007) Survival estimates of Antarctic Terns (Sterna vittata bethunei) on the Snares Islands, New Zealand. Notornis 54:214-219

Seber GAF (1982) The estimation of animal abundance and related parameters, 2nd edn. MacMillan, New York

Shealer D (2007) Population dynamics of Black Terns breeding in Southeastern Wisconsin, 1999-2007. Passenger Pigeon 69:471-478

Shealer DA, Saliva JE, Pierce J (2005) Annual survival and movement patterns of Roseate Terns breeding in Puerto Rico and the U.S. Virgin Islands. Waterbirds 28:79-86

Southern LK, Southern WE (1982) Effect of habitat decimation on Ring-billed Gull colony and nest site tenacity. Auk 99:328-331

Spendelow JA (1991) Postfledging survival and recruitment of known-origin Roseate Terns (Sterna dougallii) at Falkner Island, Connecticut. Colon Waterbirds 14:108-115

Spendelow JA, Nichols JD, Nisbet ICT, Hays H, Cormons GD, Burger J, Safina C, Hines JE, Gochfeld M (1995) Estimating annual survival and movement rates of adults within a metapopulation of Roseate Terns. Ecology 76:2415-2428

Spendelow JA, Nichols JD, Hines JE, Lebreton JD, Pradel R (2002) Modeling postfledging survival and age-specific breeding probabilities in species with delayed maturity: a case study of Roseate Terns at Falkner Island, Connecticut. J Appl Stat 29:385-405

Spendelow JA, Nichols JD, Hines JE, Nisbet ICT, Hatch JJ, Cormons GD, Hays H, Mostello CS (2008) Temporal variation in survival and movement rates of Roseate Terns during periods of increasing and declining population trends. Waterbirds 31:309-319
Spendelow JA, Mostello CS, Nisbet ICT, Hall CS, Welch L (2010) Interregional breeding dispersal of adult Roseate Terns. Waterbirds 33:242-245

StatSoft (2003) Statistica electronic manual, version 6. StatSoft, Tulsa, Okla

Suryan RM, Craig DP, Roby DD, Chelgren ND, Collis K, Shuford WD, Lyons DE (2004) Redistribution and growth of the Caspian Tern population in the Pacific Coast region of North America, 1981-2000. Condor 106:777-790

Szostek KL, Becker PH (2012) Terns in trouble: demographic consequences of low breeding success and recruitment on a common tern population in the German Wadden Sea. J Ornithol 153:313-326

Tarburton MK (1987) Migration and breeding strategies of the Black Noddy. Emu 87:50-52

Tavecchia G, Baccetti N, Serra L (2005) Colony specific variation in the use of a moulting site in the migratory little tern Sterna albifrons. J Avian Biol 36:501-509

Tomiałojć L, Stawarczyk T (2003) The avifauna of Poland distribution, numbers and trends (in Polish). Polish Society of Wildlife Friends Pro Natura, Wrocław, pp 426-429

Van der Winden J, van Horssen PW (2008) A population model for the black tern Chlidonias niger in West-Europe. J Ornithol 149:487-494

Weimerskirch H (2002) Seabird demography and its relationship with the marine environment. In: Schreiber EA, Burger J (eds) Biology of marine birds. CRC Press, Boca Raton, pp 115-135

White GC, Burnham KP (1999) Program MARK: survival estimation from populations of marked animals. Bird Study 46[Supp]:120-138

Williams K, Nichols J, Conroy M (2002) Analysis and management of animal populations: modeling, estimation and, decision making. Academic Press, San Diego 